\title{
Insights into platelet-based control of coagulation
}

Citation for published version (APA):

de Witt, S. M., Verdoold, R., Cosemans, J. M. E. M., \& Heemskerk, J. W. M. (2014). Insights into plateletbased control of coagulation. Thrombosis Research, 133, S139-S148. https://doi.org/10.1016/S0049$3848(14) 50024-2$

Document status and date:

Published: 01/05/2014

DOI:

10.1016/S0049-3848(14)50024-2

Document Version:

Publisher's PDF, also known as Version of record

Document license:

Taverne

Please check the document version of this publication:

- A submitted manuscript is the version of the article upon submission and before peer-review. There can be important differences between the submitted version and the official published version of record.

People interested in the research are advised to contact the author for the final version of the publication, or visit the DOI to the publisher's website.

- The final author version and the galley proof are versions of the publication after peer review.

- The final published version features the final layout of the paper including the volume, issue and page numbers.

Link to publication

\footnotetext{
General rights rights.

- You may freely distribute the URL identifying the publication in the public portal. please follow below link for the End User Agreement:

www.umlib.nl/taverne-license

Take down policy

If you believe that this document breaches copyright please contact us at:

repository@maastrichtuniversity.nl

providing details and we will investigate your claim.
}

Copyright and moral rights for the publications made accessible in the public portal are retained by the authors and/or other copyright owners and it is a condition of accessing publications that users recognise and abide by the legal requirements associated with these

- Users may download and print one copy of any publication from the public portal for the purpose of private study or research.

- You may not further distribute the material or use it for any profit-making activity or commercial gain

If the publication is distributed under the terms of Article $25 \mathrm{fa}$ of the Dutch Copyright Act, indicated by the "Taverne" license above, 


\title{
Insights into platelet-based control of coagulation
}

\author{
Susanne M. de Witt, Remco Verdoold, Judith M.E.M. Cosemans ${ }^{1 *}$, Johan W.M. Heemskerk ${ }^{*}$ \\ Department of Biochemistry, Cardiovascular Research Institute Maastricht (CARIM), Maastricht University, Maastricht, The Netherlands
}

A RT I C LE I NFO

\section{Keywords:}

Clot retraction

Coagulation

Platelets

Procoagulant activity

Thrombus

Fibrin

\begin{abstract}
A B S T R A C T
The coagulation process is activated by tight control mechanisms, in which platelets play prominent and unique roles. In thrombosis and hemostasis, activated platelets regulate the coagulation system in various ways: by exposing a phosphatidylserine surface for thrombin formation, by supporting fibrin formation, and by regulating the retraction of a fibrin clot. In this review we discuss the involvement of platelet receptors, other membrane proteins, downstream signaling proteins, cytoskeleton-linked proteins and plasma proteins in these procoagulant functions. Studies with both genetically modified mice and pharmacological inhibitors indicate that, for collagen-adhered platelets, in part common signaling pathways lead to phosphatidylserine exposure, generation of thrombin and fibrin, and retraction of the fibrin clot. However, prolonged $\mathrm{Ca}^{2+}$ elevation leads to thrombin generation, whereas integrin-dependent signaling stimulates fibrin clot retraction. Contact-dependent signaling pathways, triggered by homotypic platelet-platelet interactions, act in particular via the integrin route.
\end{abstract}

(c) 2014 Elsevier Ltd. All rights reserved.

\section{Introduction}

The coagulation process is regulated by tight control mechanisms. During thrombosis and hemostasis, platelets provide prominent and unique roles in supporting and confining the coagulant activity [1,2]. Particularly studies with genetically modified mice and with inhibitors using human platelets have provided detailed insights into the molecular determinants of platelet-based coagulation. In this review, we discuss these findings regarding three mechanisms, how platelets: (i) form a procoagulant surface with exposed phosphatidylserine; (ii) provide sites for thrombin and fibrin formation; and (iii) steer fibrin clot retraction (Figure 1).

\section{Regulation of platelet phosphatidylserine (PS) exposure}

Flow chamber devices have extensively been used to study the process of thrombus formation at arterial shear conditions in order to evaluate not only platelet aggregation, but also platelet procoagulant activity (PS exposure) and fibrin formation within the same experiment. The current methodology, using smallsize chambers in combination with fluorescence microscopy, has revealed key roles of many platelet receptors and signaling proteins in the buildup of a thrombus and the appearance of procoagulant platelets [3]. Table 1 provides an overview of published studies, where thrombus formation together with PS

\footnotetext{
* Corresponding authors at: Department of Biochemistry, CARIM, Maastricht University, P.O. Box 616, 6200 MD Maastricht, The Netherlands.

Tel.: +31-43-3881671; fax: +31-43-3884159.

${ }^{1}$ Equal contribution

E-mail addresses: jwm.heemskerk@maastrichtuniversity.nl (J.W.M. Heemskerk); judith.cosemans@maastrichtuniversity.nl (J.M.E.M. Cosemans).
}

exposure is assessed under arterial shear conditions using blood from genetically modified mice. Table 2 shows corresponding data with human blood and specific pharmacological inhibitors. Note that the earlier literature concentrated on understanding the role of collagen receptor-induced $\mathrm{Ca}^{2+}$ fluxes in PS exposure, while recent papers revealed the contribution of various downstream signaling events and of autocrine products secreted from platelet granules. In addition, adhesive receptors other than collagen receptors have been examined for a role in procoagulant activity.

\section{Collagen-induced $\mathrm{Ca}^{2+}$ signaling as the classical route}

At high, arterial wall-shear rate, platelet adhesion to von Willebrand factor (vWF) via glycoprotein Ib-V-IX (GPIb), and to collagen via the receptors glycoprotein VI (GPVI) and integrin $\alpha_{2} \beta_{1}$ leads to strong activation and to the formation of a stable thrombus [1,4]. A subpopulation of the platelets in the thrombus, particularly those platelets in direct contact with the collagen and the platelets that are co-activated by thrombin assume a round morphology, which is accompanied by PS exposure and microparticle shedding $[5,6]$. In contrast to the aggregated platelets in the thrombus core, the PS-exposing cells lack activation of the fibrinogen receptor, integrin $\alpha_{\mathrm{II}} \beta_{3}$ [7]. The main mechanism underlying PS exposure is a prolonged elevation in cytosolic $\mathrm{Ca}^{2+}$ level $[8,9]$. Hence, signaling molecules downstream of the GPVI-Fc receptor $\gamma$ chain (FcR $\gamma$ ) complex and involved in $\mathrm{Ca}^{2+}$ mobilization via phospholipase $\mathrm{C}_{\gamma}$ (PLC $\gamma$ ) and phosphatidylinositol 3-kinase (PI3K) will contribute to PS exposure [1]. As indicated in Table 1, platelets from knockout mice deficient in several signaling molecules show a decreased ability to thrombus formation as well as PS exposure. These signaling proteins include the receptors GPIb (via vWF), GPVI, 


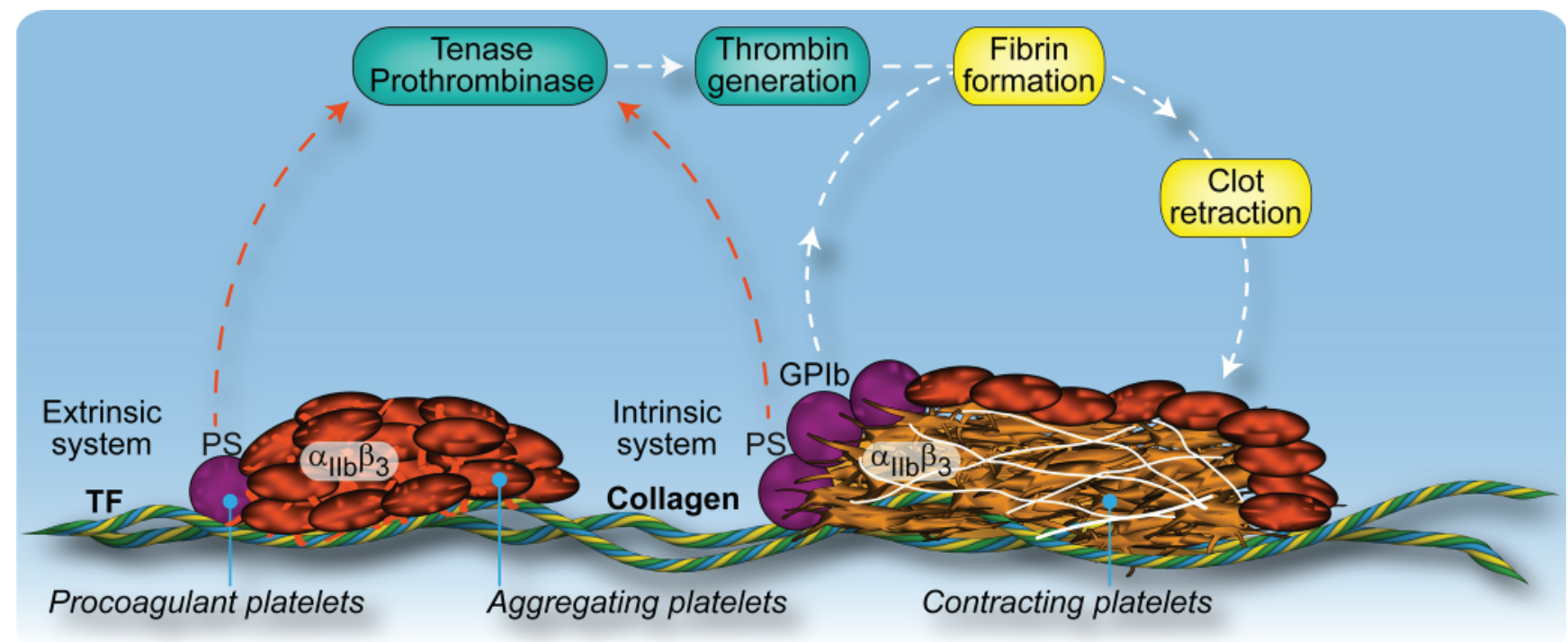

Fig. 1. Platelet-based coagulation processes in a thrombus. The extrinsic and intrinsic coagulation systems are initiated after vascular disruption via tissue factor (TF) and collagen, respectively. Collagen-adhered platelets and patches of platelets in a thrombus expose PS, which serves as an efficient surface for assembly of the tenase (factors IXa/VIIIa) and prothrombinase (factors Xa/Va) complexes, resulting in thrombin generation and fibrin formation. At low shear rates, GPIb interaction with vWF mediates focal fibrin formation at the platelet surface via PS exposure. The aggregated platelets in a thrombus display activated $\alpha_{\mathrm{II}} \beta_{3}$ and accomplish clot retraction by contracting fibrin fibers in the presence of thrombin.

Table 1

Mouse proteins and genes involved in platelet procoagulant activity and fibrin formation under high-shear flow conditions

\begin{tabular}{|c|c|c|c|c|}
\hline Target protein & Perturbation & Effect on thrombus formation & Effect on coagulation & Reference \\
\hline \multicolumn{5}{|c|}{ Platelet receptors and membrane proteins } \\
\hline Axl & $A \times l^{-1-}$ & TS $\downarrow$ (instability) & $\mathrm{PS}=$ & {$[14]$} \\
\hline Cyclophilin D & Ppid $^{-/}$ & $\mathrm{TS} \uparrow$ & PS $\downarrow$ & [7] \\
\hline Glycoprotein Ib & $\mathrm{p} 0 \mathrm{p} / \mathrm{B} \mathrm{Ab}$ & TS $\downarrow$ & PS $\downarrow$ & {$[82]$} \\
\hline Glycoprotein VI & Fcer1g-/, JAQ1 Ab & TS $\downarrow$ (no thrombi) & PS $\downarrow$ & {$[34,83,84]$} \\
\hline $\mathrm{Gq} \alpha$ & $\mathrm{Gnaq}^{--}$ & TS $\downarrow$ & PS $\downarrow$ & [83] \\
\hline Integrin $\alpha_{2} \beta_{1}$ & $\alpha_{2}$-null, $\beta_{1}$-null & TS $\downarrow$ & PS $\downarrow$ & [83-85] \\
\hline Integrin $\alpha_{\mathrm{Ib}} \beta_{3}$ & JON/A mAb & TS $\downarrow$ & PS $\downarrow$ & [82] \\
\hline LAT & Lat null, $\mathrm{Lat}^{+-}, \mathrm{Lat}^{-1-}$ & TS $\downarrow$ & PS $\downarrow$ & {$[33,34]$} \\
\hline Mer & $\mathrm{Mer}^{-1}$ & TS $\downarrow$ (instability) & $\mathrm{PS}=$ & {$[14]$} \\
\hline Orai1 & Orai1 ${ }^{-}, 2-\mathrm{APB}$ & TS $\downarrow$ & PS $\downarrow$, fibrin $\downarrow$ & {$[17,18]$} \\
\hline $\mathrm{P}_{2} \mathrm{Y}_{1}$ & MRS-2179 & TS $\downarrow$ & PS $\downarrow$ & [83] \\
\hline $\mathrm{P}_{2} \mathrm{Y}_{12}$ & P2yr12 ${ }^{-/}$, cangrelor & TS $\downarrow$ & PS $\downarrow$ & {$[12]$} \\
\hline \multirow[t]{2}{*}{ STIM1 } & Stim $1^{--}$ & TS $\downarrow$ & PS $\downarrow$, fibrin $\downarrow$ & [17] \\
\hline & Stim1 (LOF) & $\mathrm{TS}=$ & $\mathrm{PS}=$ & [23] \\
\hline Tyro3 & Tyro3 ${ }^{--}$ & TS $\downarrow$ (instability) & $\mathrm{PS}=$ & {$[14]$} \\
\hline \multicolumn{5}{|c|}{ Platelet signaling proteins (kinases) } \\
\hline PI3 kinases & Pik3r1/, wortmannin & TS $\downarrow$ & PS $\downarrow$ & {$[27]$} \\
\hline PI3 kinase $\alpha / \beta$ & PIK-75, TGX-221, Pik3r2 (LOF) & TS $\downarrow$ & PS $\downarrow$ & {$[27,48,86]$} \\
\hline Protein kinase $\mathrm{C} \alpha$ & $\mathrm{PrkCa}^{-/-}$ & TS $\downarrow$ & PS $\downarrow$ & {$[87,88]$} \\
\hline Protein kinase $C \beta$ & Prkcb $^{-/}$ & TS $\downarrow$ (no thrombi) & PS $\downarrow$ & [87] \\
\hline Protein kinase $C \delta$ & Prkcd $^{-/}$ & TS $\uparrow$ & PS $=$ & {$[87]$} \\
\hline Protein kinase $\mathrm{C} \theta$ & Prkcq ${ }^{-/}$ & TS $\uparrow / \downarrow$ & $\mathrm{PS} \uparrow$ & {$[26,87]$} \\
\hline Protein kinase D2 & $P k d 2^{-}-$ & TS $\downarrow$ & $\mathrm{PS}=$ & [89] \\
\hline Src family kinases & PD0173952 & TS $\downarrow$ (no thrombi) & PS $\downarrow$ & {$[33,85]$} \\
\hline \multicolumn{5}{|c|}{ Platelet signaling proteins (non-kinases) } \\
\hline$\alpha$-Granules & Nbeal2\% & TS $\downarrow$ & PS $\downarrow$ & {$[30]$} \\
\hline CalDAG-GEF1 & Rasgrp $^{-/}$ & TS $\downarrow$ & PS $\downarrow$ & [23] \\
\hline Calpain-1 & Capn $1^{-/}$ & $\mathrm{TS}=$ & PS $\downarrow$ & [7] \\
\hline CLP36 & Clp36 (LOF) & $\mathrm{TS} \uparrow$ & $\mathrm{PS} \uparrow$ & [31] \\
\hline Gas6 & Gas6-1- & TS $\downarrow$ (instability) & $\mathrm{PS}=$ & [14] \\
\hline \multirow[t]{2}{*}{ Phospholipase $\mathrm{C}_{\gamma} 2$} & Plcg2(GOF), & TS $\uparrow$ & $\mathrm{PS} \uparrow$ & [90] \\
\hline & $\mathrm{Plcg}^{+/-}, \mathrm{Plcg}^{--}$ & TS $\downarrow$ & PS $\downarrow$ & [34] \\
\hline Phospholipase D1 & Pld $1^{-}$ & TS $\downarrow$ & PS $\downarrow$ & {$[54]$} \\
\hline \multicolumn{5}{|l|}{ Plasma proteins } \\
\hline Factor XI & $F 11^{--}$ & $\mathrm{TS} \downarrow$ & PS $\downarrow$, fibrin $\downarrow$ & [34] \\
\hline Factor XII & $F 12^{-/}$, CTI & TS $\downarrow$ & PS $\downarrow$, fibrin $\downarrow$ & [34] \\
\hline Factor VII & FVIIai & TS $\downarrow$ & PS $\downarrow$, fibrin $\downarrow$ & [34] \\
\hline (Pro)thrombin & melagatran & TS $\downarrow$ & PS $\downarrow$, fibrin $\downarrow$ & [35] \\
\hline VWF & saratin & TS $\downarrow$ & PS $\downarrow$ & {$[33,82]$} \\
\hline
\end{tabular}

$\mathrm{Ab}$, antibody; GOF, gain-of-function; LOF, loss-of-function; PS, phosphatidylserine, TS, thrombus size; = unchanged; $\uparrow$ increased; $\downarrow$ decreased. 
Table 2

Human proteins involved in platelet procoagulant activity and fibrin formation under high-shear flow conditions

\begin{tabular}{|c|c|c|c|c|}
\hline Target protein & Intervention & Effect on thrombus & Effect on coagulation & Reference \\
\hline \multicolumn{5}{|c|}{ Platelet receptors and membrane proteins } \\
\hline Glycoprotein Ib & $6 \mathrm{~B} 4,12 \mathrm{G} 1 \mathrm{Abs}$ & TS $\downarrow$ & PS $\downarrow$ & {$[91]$} \\
\hline Glycoprotein VI & $9012,10 \mathrm{~B} 12 \mathrm{Abs}$ & TS $\downarrow$ (no thrombi) & PS $\downarrow$ & {$[11,92,93]$} \\
\hline Integrin $\alpha_{2} \beta_{1}$ & $6 \mathrm{~F} 1,15 \mathrm{D} 7 \mathrm{Abs}$ & TS $\downarrow$ & PS $\downarrow$ & {$[85,92-94]$} \\
\hline Integrin $\alpha_{\mathrm{IIb}} \beta_{3}$ & agrastat, latrofiban & TS $\downarrow$ (no thrombi) & PS $\downarrow$ & {$[85,94]$} \\
\hline Orai1 & $2-\mathrm{APB}$ & TS $\downarrow$ & PS $\downarrow$ & {$[18]$} \\
\hline $\mathrm{P} 2 \mathrm{Y}_{12}$ & ticagrelor, cangrelor & TS $\downarrow$ (instability) & PS $\downarrow$, fibrin $\downarrow$ & {$[11,12,48]$} \\
\hline \multicolumn{5}{|c|}{ Platelet signaling proteins (kinases) } \\
\hline PI3 kinases & wortmannin & TS $\downarrow$ (instability) & PS $\downarrow$ & {$[27,48]$} \\
\hline PI3 kinase $\alpha / \delta$ & PIK-75, YM-024 & TS $\downarrow$ & PS $\downarrow$ & [27] \\
\hline PI3 kinase $\beta$ & TGX-221 & TS $\downarrow$ & PS $\downarrow$ & [27] \\
\hline PI3 kinase $\gamma$ & AS-252424 & $\mathrm{TS}=$ & $\mathrm{PS}=$ & [27] \\
\hline PI3 kinase $\delta$ & IC-87144 & $\mathrm{TS}=$ & $\mathrm{PS}=$ & [27] \\
\hline Protein kinase C & GF-109203X, RO-318425 & TS $\downarrow$ (no thrombi) & $\mathrm{PS} \uparrow$ & [25] \\
\hline Src family kinases & PD-0173952 & TS $\downarrow$ (no thrombi) & PS $\downarrow$ & [85] \\
\hline
\end{tabular}

Abbreviations as for Table 1 .

FcR $\gamma, \alpha_{2} \beta_{1}$ and $\alpha_{\mathrm{IIb}} \beta_{3}$; various adapter and scaffold proteins, e.g. linker for activated T-cells (LAT); effector proteins such as the PI3K isoforms $\alpha / \beta$, Src family kinases, and PLC $\gamma 2$. Inhibitory studies with human blood indicate a similar involvement of receptors (GPIb, GPVI, $\alpha_{2} \beta_{1}, \alpha_{\mathrm{IIb}} \beta_{3}$ ) and signaling molecules (PI3K isoforms $\alpha$ and $\beta$ and Src family kinases) in thrombus formation and PS exposure (Table 2). These findings support the concept that the reduced PS exposure is a direct consequence of diminished GPVI signaling to elevated $\mathrm{Ca}^{2+}$, rather than to a reduced platelet deposition per se [9].

Collagen- and GPVI-dependent PS exposure is greatly enhanced by co-stimulation of platelets with thrombin (acting via the Gq $\alpha$ protein), at both static and flow conditions, an effect that is explained by the more prolonged $\mathrm{Ca}^{2+}$ mobilization in response to two agonists [10]. Other soluble agonists, in particular $\mathrm{ADP}$, have been shown to enforce GPVI-induced $\mathrm{Ca}^{2+}$ signaling, $\mathrm{PS}$ exposure and thrombin generation, particularly via the $\mathrm{P}_{2} \mathrm{Y}_{12}$ receptors, and hence contribute to platelet procoagulant activity. Consequently, knock-out (mouse) or inhibition (human) of P2Y resulted in a smaller thrombus size and decreased PS exposure [11-13]. However, thrombus formation not always coincides with PS exposure. For instance, the interaction of plasma-derived Gas6 with the platelet Gas6 receptors (TAM receptors), while enforcing integrin activation and contributing to thrombus stability, did not contribute to platelet PS exposure [5,14].

\section{Insights into the role of elevated $\mathrm{Ca}^{2+}$}

Platelets contain well-developed $\mathrm{Ca}^{2+}$ entry mechanisms for inducing and maintaining high cytosolic $\mathrm{Ca}^{2+}$ levels [15]. Recent work has pointed to a role of the so-called store-operated and receptor-operated $\mathrm{Ca}^{2+}$ entry pathways in PS exposure. The integral membrane protein, stromal interaction molecule (STIM)1, has been identified as the central $\mathrm{Ca}^{2+}$ sensor in the platelet reticular membrane that regulates store-operated $\mathrm{Ca}^{2+}$ entry [16]. Via a direct coupling mechanism, STIM1 activates the $\mathrm{Ca}^{2+}$ entry channel Orai1. Deficiency in either STIM1 or Orai1 resulted in decreased thrombus formation and PS exposure on collagen (Figure 2A) [17,18]. Interestingly, in the presence of high thrombin concentrations, STIM and Orai1 appeared to be less important for PS exposure [17]. This was recently explained by the finding that thrombin-dependent $\mathrm{Ca}^{2+}$ signaling in part relies on receptor-operated $\mathrm{Ca}^{2+}$ entry via TRPC channels [19].

The $\mathrm{Ca}^{2+}$ signal in procoagulant platelets is enhanced by the release of mitochondrial $\mathrm{Ca}^{2+}$ via mitochondrial permeability transition pore formation (Figure 2A) [20]. A key regulator in this pore formation is the mitochondrial localized peptidylprolylisomerase, cyclophilin D [21]. Accordingly, GPVIinduced PS exposure was found to be reduced in platelets from mice lacking cyclophilin D [7]. However, in these platelets ionomycin-induced PS exposure is unchanged [22], designating that mitochondrial collapse as such is not a strict requirement for PS exposure.

\section{Redundancies downstream of diacylglycerol and $\mathrm{Ca}^{2+}$}

Isoforms of PLC produce two second messengers, diacylglycerol (DAG) and inositol-trisphosphate serving as an intracellular $\mathrm{Ca}^{2+}$ mobilizer. Recent investigations have examined the roles in platelet procoagulant activity of two sets of $\mathrm{Ca}^{2+}$ and DAG-dependent effector proteins, which are activated downstream of PLC $\gamma 2$, namely CalDAG-GEF1 and isoforms of protein kinase $C(\mathrm{PKC})$. Interestingly, these effector proteins can also modulate the $\mathrm{Ca}^{2+}$ signal itself, in a not yet completely understood way (Figure 2A). Platelets from mice lacking CalDAGGEF1 are greatly impaired in thrombus formation as well as in PS exposure [23]. However, the situation for PKC is more complex as described next.

Human and mouse platelets express both the conventional PKC isoforms $\alpha$ and $\beta$ and the novel PKC isoforms $\delta$ and $\theta$ [24]. In human blood, addition of a general inhibitor for all PKC isoforms resulted in greatly abolished thrombus formation, but in increased PS exposure of the remaining adhered platelets [25]. Studies with knockout mice indicated a positive role in both thrombus formation and PS exposure of the two conventional PKC isoforms $\alpha / \beta$, whereas the two novel PKC isoforms $\delta / \theta$ were inhibitory $[26,27]$. The precise phosphorylation events through which these PKC isoforms operate are still unclear [24]. Jointly, these data point to non-redundant and positive roles of CalDAGGEF1 and PKC $\alpha / \beta$, and to antagonistic and negative roles of $\mathrm{PKC} \delta / \theta$ in the regulation of thrombus buildup and PS exposure.

Calpain is another $\mathrm{Ca}^{2+}$-dependent effector protein controlling platelet activation. While deficiency in mouse calpain-1 had no effect on thrombus size, this resulted in a markedly lower PS exposure [7,22].

\section{Additive roles of dense- and alpha-granule secretion}

Platelet dense $(\delta)$ and alpha $(\alpha)$ granule constituents are known to amplify platelet responses, such in agreement with the bleeding phenotype seen in patients with platelets lacking these granules [28]. Novel data indicate that granule secretion 

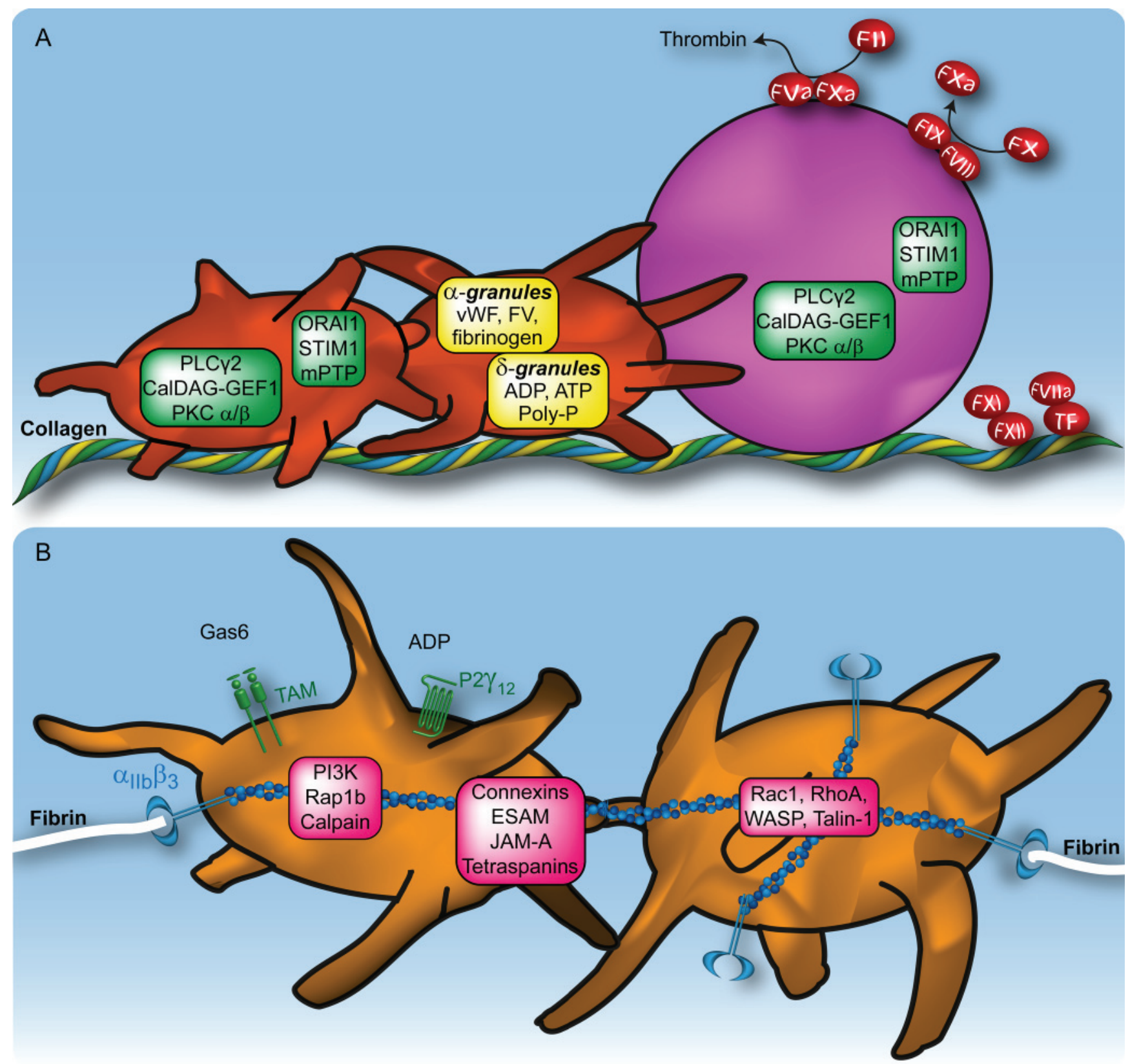

Fig. 2. Signaling pathways implicated in platelet-dependent procoagulant activity, thrombin generation and clot retraction. (A) Platelets on collagen signal to second messenger generation (PLC $\gamma 2$, CalDAG-GEF1, PKC isoforms) and $\mathrm{Ca}^{2+}$ mobilization combined with store-operated Ca ${ }^{2+}$ entry (STIM1, Orai1) and release of mitochondrial $\mathrm{Ca}^{2+}$ via mPTP formation, resulting in sustained high cytosolic $\mathrm{Ca}^{2+}$ levels, granule secretion and PS exposure. These processes are supported by $\alpha$ - and $\delta$-granule constituents. The PS-exposing platelets show procoagulant activity by catalyzing tenase and prothrombinase activities (see also Figure 1 ). (B) Continuous inside-out signaling via PI3K, Rap1b and calpain leads to sustained $\alpha_{m b} \beta_{3}$ activation, enabling integrin outside-in mediated actin cytoskeleton reorganization via Rac1, RhoA, WASP and talin resulting in clot retraction. Homotypic interactions via connexins, ESAM and JAM-A differentially regulate clot retraction, while tetraspanins may directly interact with $\alpha_{\mathrm{II}} \beta_{3}$.

supports not only platelet aggregation, but also platelet procoagulant activity. The $\delta$-granules contain calcium, serotonin, ADP, ATP and polyphosphates. The observed impairment of collagen/thrombin-induced PS exposure of platelets deficient in $\mathrm{P}_{2} \mathrm{Y}_{12}$ or in the presence of $\mathrm{P} 2 \mathrm{Y}_{12}$ inhibitors [12,13], can well be explained by inability of secreted ADP to interact with this receptor on neighboring platelets and thereby diminished signaling to platelet procoagulant activity. Lack of $\delta$-granules is the underlying cause of the Hermansky-Pudlak bleeding disorder [28]. Mice deficient in one of the Hermansky-Pudlak genes (Hsp3) show an impaired thrombosis tendency in vivo, but PS exposure has not yet been assessed.
The $\alpha$-granules store multiple proteins, several of which can support thrombus formation, e.g. vWF, fibrinogen, factor $\mathrm{V}$ and thrombospondin [29]. Mutations in the Nbeal2 gene associate with gray platelet syndrome, a rare bleeding disorder characterized by macrothrombocytopenia and the absence of platelet $\alpha$-granules. Mice lacking expression of the Nbeal2 gene have been reported to be decreased in both thrombus formation and PS exposure [30]. These mice provide an excellent model for further determination of the roles of $\alpha$-granule proteins in hemostasis, thrombosis and inflammation.

Secretion of both $\alpha$ - and $\delta$-granules is increased in CLP36deficient mice, thus explaining a larger thrombus size and 
higher PS exposure of these platelets under flow [31]. CLP36 is an adaptor protein that binds to $\alpha$-actinin- 1 and associates with actin filaments and stress fibers [32]. Jointly, these findings seem to indicate that both types of secretion granules have additive roles in PS exposure along with thrombus formation (Figure 2A).

\section{Regulation of platelet-dependent thrombin generation and fibrin formation}

Platelet membranes with exposed PS provide an efficient surface for assembly of the tenase (factors IXa, VIIIa) and prothrombinase (factors $\mathrm{Xa}, \mathrm{Va}$ ) complexes, accomplishing high thrombin generation and subsequent fibrin formation [1]. Interestingly, genetic ablation or pharmacological inhibition of factors of either the extrinsic (VII) or the intrinsic (XII, $\mathrm{XI}$ ) coagulation pathways diminished thrombin generation under stasis (Tables 3-4). Several of the signaling proteins that contribute to GPVI-induced PS exposure under flow have also been shown to control GPVI-mediated thrombin generation under stasis, as depicted for GVPI, PI3K $\beta$, Syk, Orai1, STIM1 and P2Y ${ }_{12}$.

Strikingly, platelets bind almost all coagulation factors, including thrombin and fibrin [8]. At high shear rate in the presence of tissue factor, fibrin is predominantly confined to the core of platelet thrombi, which implies platelet support of the extrinsic coagulation system, triggered by the tissue factor/factor VIIa complex [33]. Studies carried out in the absence of tissue factor also point to a role of the intrinsic coagulation system via factors XI and XII. In flow studies on collagen with recalcified blood, collagen fibers were found to play a dual role, i.e. as a ligand for GPVI resulting in platelet activation, and as a substrate for the binding and activation of factor XII [34]. Consequently, deficiency in factor XII or XI resulted in a decreased thrombus size, reduced PS exposure, and delayed fibrin formation (Table 1). Inhibition of thrombin was even more suppressive [35]. Of note, signaling downstream of $\mathrm{P}_{2} \mathrm{Y}_{12}$ amplified these processes [12,13]. Factor XIIa may also play another role, i.e. by directly binding to fibrin and regulating clot structure [36]. Jointly, these findings point to involvement of both the intrinsic and extrinsic coagulation systems in thrombin generation and ensuing fibrin formation at high-shear flow conditions. Furthermore, the formed thrombin generates a positive feed-forward loop to enhanced PS exposure via activation of the PAR receptors on platelets [8].

Classically, insufficiently controlled coagulation is regarded as a cause of thrombosis under venous shear conditions. Recently, several insights also point to a role of platelets, in interplay with vWF and coagulation factors, in the thrombotic process under flow at low, venous wall-shear rates. In the absence of anticoagulants and low shear rate (implying accumulation of thrombin), a fibrin network is formed on the platelet surface with an outward-directed star-like appearance [37]. This focal fibrin formation relies on vWF-GPIb interactions, causing rises in cytosolic $\mathrm{Ca}^{2+}$ and PS exposure [37]. The signaling mechanism may involve GPIb-dependent changes of the actin cytoskeleton $[38,39]$. Interestingly, the fibrin fibers incorporate thrombin that seems to be relocating from PS-exposing and factor Xa-binding platelets [40].

The role of neutrophils in murine venous thrombosis models recently received much attention. It is reported that neutrophils, which are trapped in murine veins subjected to partial stasis, produce neutrophil extracellular traps (NETs), i.e. large extracellular DNA strands fibers surrounded by histones and neutrophil antimicrobial proteins [41]. In venous and microvascular thrombosis models, NETs formation can be a stimulus and scaffold for the formation of large thrombi of platelets, fibrin and erythrocytes [41,42]. Furthermore, NETs can be formed in the vasculature during sepsis, where they may help to reduce microbial infections $[43,44]$. The underlying mechanisms of platelet responses to neutrophils and NETs have to be elucidated.

\section{Towards understanding platelet-dependent fibrin clot retraction}

In hemostasis, the process of platelet-dependent clot retraction provides a means to tighten wound edges after clotting [45]. Especially under conditions of coagulation and fibrin formation, thrombi that are formed under flow can undergo a mechanism of retraction, which can be considered as an equivalent process as clot retraction [8]. However, clot retraction as such has mostly been examined under static conditions, e.g. by determining the condensation of a platelet/fibrin clot in thrombin-stimulated platelet-rich-plasma. In general, clot retraction is regarded as a platelet response evoked by $\alpha_{\mathrm{IIb}} \beta_{3}$ inside-out signaling, thus implying dependency of (thrombin-induced) $\alpha_{\mathrm{Ib}} \beta_{3}$ activation and binding of fibrinogen to platelets [46]. Table 3 provides an overview of published effects of genetic knockout in mouse on clot retraction, while Table 4 gives corresponding data for human blood. Below we describe new insights into the molecular mechanisms with emphasis on integrin inside-out and outsidein signaling, homotypic platelet-platelet interactions, and the role of the actin cytoskeleton.

\section{Enforcement of $\alpha_{I I b} \beta_{3}$ inside-out signaling}

While clot retraction for long has been recognized as a process that reflects integrin outside-in signaling, new data provide insight into the underlying signaling events in platelets via activated integrins. The ADP receptor $\mathrm{P}_{2} \mathrm{Y}_{12}$ prolongs integrin activation and platelet aggregation [47]. Continued signaling via this receptor (via Gi and PI3K $\beta$ ) maintains $\alpha_{\mathrm{II}} \beta_{3}$ in the active conformation and thus prevents platelet disaggregation $[48,49]$. Likely, similar signaling mechanisms are implicated in clot retraction, since mouse platelets lacking integrin $\beta_{3}$ or PI3K $\beta$ are impaired in this process (Table 3, Figure 2B).

An enforcement loop that acts in a similar, though weaker way is that of (plasma-derived) Gas6 interacting with the platelet Gas6 receptors, also called TAM receptors (Tyro3, Axl and Mer). Activation of these receptors by Gas6 supports platelet aggregation and tyrosine phosphorylation of the $\beta_{3}$ integrin chain, again in a PI3K-dependent way [47,50]. Overall, TAM receptor signaling can enforce the activation of $\alpha_{\text {II }} \beta_{3}$, and thus help to prevent platelet disaggregation. Platelets from mice deficient in one of the TAM receptors have a decreased ability to clot retraction, which supports a role for Gas6 and its receptors in integrin outside-in signaling (Figure 2B) [50].

Calcium also play a central role in integrin activation via the $\mathrm{Ca}^{2+}$ - and DAG-dependent effector proteins CalDAG-GEF1 and isoforms of PKC, which are activated downstream of PLC $\gamma 2$. Activation of Rap1b - via CALDAG-GEF or PKC - promotes the assembly of an activation complex with RIAM (Rap1 interacting adaptor molecule) and talin. Cleavage of talin mediated by RIAM, calpain and phosphatidylinositol 4,5-biphosphate ( $\mathrm{PIP}_{2}$ ) enables talin binding to the integrin $\beta_{3}$ chain, thereby activating the integrin and enabling ligand binding [51]. An additional level of regulation is provided by phospholipase D (PLD) 1 and 2. Both isoforms are present in platelets and translocate to the plasma membrane during platelet activation and produce phosphatidic acid to stimulate the production of $\mathrm{PIP}_{2}[52,53]$. Mice deficient in PLD1 display impaired thrombus formation and PS exposure due to impaired integrin $\alpha_{\mathrm{II}} \beta_{3}$ inside-out signaling [54]. Fibrin clot retraction is also reduced in these mice, similarly as in mice lacking Rap1b or talin [54,103,104]. 
Table 3

Mouse proteins and genes involved in platelet-dependent thrombin generation and clot retraction under stasis.

\begin{tabular}{|c|c|c|c|c|}
\hline & Target protein & Perturbation & Effect on coagulation & Reference \\
\hline \multicolumn{5}{|c|}{ Platelet receptors and membrane proteins } \\
\hline & Axl & $A x^{-1-}$ & $\mathrm{CR} \downarrow$ & {$[50]$} \\
\hline & Connexin 37 & $\mathrm{Gja4}^{-/}$ & $\mathrm{CR} \downarrow$ & [59] \\
\hline & Connexin 40 & Gja5\% & $\mathrm{CR} \downarrow$ & {$[60]$} \\
\hline \multirow[t]{3}{*}{ * } & Cyclophilin D & Ppid $^{-1-}$ & $\mathrm{CR} \downarrow$ & [22] \\
\hline & ESAM & $E S A M^{-/-}$ & $\mathrm{CR} \downarrow$ & [67] \\
\hline & Galectin-1 & Lgals $1^{-/-}$ & $\mathrm{CR} \downarrow$ & [55] \\
\hline \multirow[t]{3}{*}{ * } & Integrin $\alpha_{\mathrm{Ib}} \beta_{3}$ & $\beta_{3}$-null & $\mathrm{CR} \downarrow$ & [95] \\
\hline & JAM-A & F11r $r^{-}$ & $\mathrm{CR} \uparrow$ & [61] \\
\hline & Mer & Mer-- & $\mathrm{CR} \downarrow$ & {$[50]$} \\
\hline * & Orai1 & Orai ${ }^{-1}$ & TG $\downarrow$ & [17] \\
\hline \multirow[t]{2}{*}{ * } & $\mathrm{P} \mathrm{Y}_{12}$ & cangrelor, ticagrelor & TG $\downarrow$ & {$[11-13]$} \\
\hline & PECAM-1 & Pecam $1^{-1-}$ & $\mathrm{CR}=$ & {$[72]$} \\
\hline \multirow[t]{5}{*}{ * } & STIM1 & Stim $1^{-1-}$ & TG $\downarrow$ & [17] \\
\hline & Tetraspanin 32 (TSSC6) & Tspan32-- & $\mathrm{CR} \downarrow$ & [70] \\
\hline & Tetraspanin CD151 & Cd151\% & $\mathrm{CR} \downarrow$ & [71] \\
\hline & TMEM16F (anoctamin 6) & Ano6-1- & TG $\downarrow$ & [96] \\
\hline & Tyro3 & Tyro3-- & $\mathrm{CR} \downarrow$ & [50] \\
\hline \multicolumn{5}{|c|}{ Platelet signaling proteins (kinases/phosphatases) } \\
\hline & AMPK $\alpha 2$ & Prkaa2 & $\mathrm{CR} \downarrow$ & {$[97]$} \\
\hline & PDK1 & Pdpk $1^{\%}$, Pdpk1 (LOF) & $\mathrm{CR} \downarrow$ & [98] \\
\hline * & PI3 kinase & LY-294002 & $\mathrm{CR} \downarrow$ & [76] \\
\hline \multirow[t]{10}{*}{ * } & PI3 kinase $\beta$ & Pik3cb-null, TGX-221 & $\mathrm{CR} \downarrow$ & [75] \\
\hline & Protein phosphatase $1 \gamma$ & Ppp $1 c c^{-/}$ & $\mathrm{CR} \downarrow$ & [99] \\
\hline & PTP1B & Ptpn $1^{--}$ & $\mathrm{CR}=\mid \downarrow$ & {$[100,101]$} \\
\hline & \multicolumn{4}{|l|}{ Cytoskeleton linked proteins } \\
\hline & Rac1 & EHT-1864 & $\mathrm{CR} \downarrow$ & [102] \\
\hline & Rap1b & $\operatorname{Rap}_{1} b^{-/}$ & $\mathrm{CR} \downarrow$ & [103] \\
\hline & RhoA & Rhoa $^{-/}$ & $\mathrm{CR} \downarrow$ & [79] \\
\hline & Talin-1 & Tln1-null & $\mathrm{CR} \downarrow$ & [104] \\
\hline & WASP & Wasp ${ }^{-/}$ & $\mathrm{CR} \downarrow$ & [81] \\
\hline & \multicolumn{4}{|c|}{ Platelet signaling proteins (other) } \\
\hline * & Calpain & Capn $1^{-}$ & $\mathrm{CR} \downarrow$ & {$[100]$} \\
\hline & $\mathrm{Cbl}$ & $\mathrm{Cbl}^{-}, \mathrm{Cbl}(\mathrm{LOF})$ & $\mathrm{CR} \downarrow$ & {$[105]$} \\
\hline & Gas6 & Gas6 $^{-1-}$ & $\mathrm{TG}=$ & [14] \\
\hline & Lnk & $\operatorname{Sh} 2 b 3^{-1-}$ & $\mathrm{CR} \downarrow$ & [106] \\
\hline & mTOR & rapamycin & $\mathrm{CR} \downarrow$ & {$[107]$} \\
\hline & $N F-\kappa B$ & BAY-117082 & $\mathrm{CR} \downarrow$ & [108] \\
\hline & PER2 & Per2-null & $\mathrm{CR} \downarrow$ & [109] \\
\hline & Phosphodiesterase 3 & milrinone & TG $\downarrow$ & [110] \\
\hline \multirow[t]{3}{*}{ * } & Phospholipase $C_{\gamma} 2$ & Plcg2-广- & $\mathrm{CR} \downarrow$ & [111] \\
\hline & SHIP1 ( $\mathrm{PIP}_{3}$ phosphatase) & Inpp55-null & $\mathrm{CR} \downarrow$ & {$[112]$} \\
\hline & \multicolumn{4}{|l|}{ Plasma proteins } \\
\hline$*$ & Factor XII & $F 12^{-/,}$, CTI & $\mathrm{TG} \downarrow$ & [34] \\
\hline * & Factor XI & $F 11^{-/-}$ & TG $\downarrow$ & [34] \\
\hline$*$ & Factor VII & FVIIai & TG $\downarrow$ & [34] \\
\hline * & (Pro)thrombin & melagatran & $\mathrm{TG} \downarrow$ & [35] \\
\hline
\end{tabular}

Abbreviations: see Table 1. In addition: CR clot retraction; TG thrombin generation; * also involved in PS exposure, see Table 1.

Recently, galectin-1 has been recognized as a new platelet agonist perhaps acting by direct activation of $\alpha_{\mathrm{II}} \beta_{3}$. Galactin-1 binding to platelets evokes common activation signals, such as $\mathrm{Ca}^{2+}$ mobilization, phosphorylation of PLC $\gamma 2$, Syk and mitogenactivated protein kinases [55]. Mice lacking galectin-1 were found to be impaired in clot retraction, likely because of diminished outside-in signaling.

\section{Homotypic interactions regulating $\alpha_{I I b} \beta_{3}$ activity}

Platelets contain a whole repertoire of receptors and signaling molecules that regulate the formation of tight platelet-platelet contacts and can trigger contact-dependent signaling events via homotypic interactions [56]. Among these are proteins forming gap junctions via the inter-cellular coupling of two hemichannels between adjacent cells [57,58]. Two members of the family of connexins - implicated in hemichannel formation - i.e. connexins
37 and 40, are highly expressed in platelets. Knockout (mouse) and inhibitor (human) studies indicated that both connexins participate in platelet-dependent clot retraction [59,60]. Surprisingly, however, these connexins also appeared to contribute to other activation processes, such as platelet aggregation, integrin activation, $\mathrm{Ca}^{2+}$ signaling and $\alpha$-granule secretion [59]. Hence, it seems that connexins have an overall role in the platelet activation process, rather than a specific role in tight junction formation during clot retraction. Clearly, more research is needed to elucidate the precise action mechanisms of platelet connexins.

Junctional adhesion molecule (JAM)-A is another established molecule exhibiting homotypic interactions in platelets [61,62]. Recently, JAM-A was identified as a negative regulator of platelet activation and, hence, of thrombus formation [61]. Along the same line, integrin outside-in signaling and clot retraction were increased in mouse platelets lacking JAM-A. Earlier data suggested that JAM-A acts as a co-receptor for stimulatory antibodies via 
Table 4

Human proteins involved in platelet-dependent thrombin generation and clot retraction coagulation under stasis

\begin{tabular}{|c|c|c|c|c|}
\hline & Target protein & Intervention & Effect on coagulation & Reference \\
\hline & \multicolumn{4}{|c|}{ Platelet receptors and membrane proteins } \\
\hline & IP receptor & prostaglandin $\mathrm{E}_{1}$ & TG $\downarrow$ & {$[113,114]$} \\
\hline & G13 protein & mSRI peptide & $\mathrm{CR} \downarrow$ & {$[115]$} \\
\hline & Gap junctions & carbenoxolone, Gap27, 18 $\beta-G A$ & $\mathrm{CR} \downarrow$ & [59] \\
\hline * & Glycoprotein VI & $9012 \mathrm{Ab}$ & TG $\downarrow$ & {$[113,114]$} \\
\hline * & Integrin $\alpha_{2} \beta_{1}$ & $6 \mathrm{~F} 1 \mathrm{Ab}$ & TG $\downarrow$ & [113] \\
\hline * & Integrin $\alpha_{\mathrm{II}} \beta_{3}$ & Glanzmann patients, abciximab & $\mathrm{CR} \downarrow, \mathrm{TG} \downarrow$ & {$[113,114,116]$} \\
\hline * & Orai1 & $2-\mathrm{APB}$ & TG $\downarrow$ & {$[18]$} \\
\hline * & $\mathrm{P} 2 \mathrm{Y}_{12}$ & cangrelor, ticagrelor & TG $\downarrow$ & {$[12,113,114,117]$} \\
\hline \multicolumn{5}{|c|}{ Platelet signaling proteins (kinases) } \\
\hline * & PI3 kinase $\beta$ & TGX-221 & TG $\downarrow$ & [117] \\
\hline & SFK & PD0173952 & $\mathrm{CR} \downarrow$ & [78] \\
\hline & Syk & Syk inhibitor II & TG $\downarrow$ & [118] \\
\hline \multicolumn{5}{|c|}{ Platelet signaling proteins (non-kinases) } \\
\hline & Cbl & OXSI-2, PP2 & $\mathrm{CR} \downarrow$ & {$[105]$} \\
\hline & Cyclooxygenase & aspirin & TG $\downarrow$ & [113] \\
\hline & WASP & WAS patients & $\mathrm{CR} \downarrow$ & {$[81]$} \\
\hline \multicolumn{5}{|c|}{ Plasma proteins } \\
\hline & Factor XII & Corn trypsin inhibitor & TG $\downarrow$ & {$[34]$} \\
\hline & Factor VII & FVIIai & TG $\downarrow$ & [34] \\
\hline
\end{tabular}

For abbreviations, see Table 3.

interaction with the Fc $\gamma$ RIIA receptor on human platelets [63,64]. The mechanism proposed is suppression by JAM-A of integrin outside-in signaling through downstream protein kinases, such as Src, Syk and focal adhesion kinase [65,66]. An earlier suggestion, that JAM-A interferes with fibrinogen binding to the activated integrin, could not be confirmed in recent work [61].

In spite of the examples above, integrin outside-in signaling and clot retraction are not always affected in the same ways. In platelets lacking endothelial cell specific adhesion molecule (ESAM), spreading on immobilized fibrinogen (reflecting outside-in signaling) was unaffected, while fibrin clot retraction was delayed [67]. Similarly to connexins and JAM-A, also ESAM is considered to cluster platelets via homotypic interactions.

Platelet integrins form multi-molecular complexes with other membrane proteins such tetraspanins. Reported are high expressions of tetraspanin-32,CD151,CD9 and CD63 [68]. It has been suggested that tetraspanins support integrins in the regulation of contact-dependent signaling [69]. Although the precise molecular mechanism is still unclear, tetraspanin interaction with integrins is likely, since deficiency in tetraspanin-32 or CD151 was found to lead to impaired clot retraction $[70,71]$.

Another 'difficult' membrane protein in terms of platelet function is PECAM-1. Platelets from mice lacking PECAM-1 have been reported as no more than slightly impaired in agonistinduced responses, with unchanged clot retraction [72]. This is in contrast to an earlier detected inhibitory role of PECAM-1 in human platelet function $[73,74]$. The reason for this discrepancy is unclear. Taken together, the various platelet proteins implicated in homotypic interactions seem to contribute in a balanced way (positive and negative) to platelet clot retraction, often in a similar way as to integrin activation (Figure 2B).

\section{Actin cytoskeleton rearrangement}

Traditionally, clot retraction is thought to be a thrombin- and fibrin-dependent process initiated by fibrin binding to $\alpha_{\mathrm{IIb}} \beta_{3}$. Subsequent actin and myosin cytoskeleton rearrangements generate contracting forces that are transmitted to the fibrin clot (Figure 2B) [75, 76]. More recent findings point to the existence of a clot retraction mechanism involving Rho kinase and Src family kinases, which precedes the actin-dependent process $[77,78]$.
In agreement with this, genetic ablation of RhoA was found to diminish clot retraction [79]. Furthermore, integrin-dependent phosphorylation by Src and Syk kinases of the ubiquitin ligase $\mathrm{Cbl}$ leads to the recruitment of $\mathrm{SH} 2$-domain containing proteins that mediate platelet spreading and clot retraction [80].

The Wiskott-Aldrich syndrome, caused by a deficiency in the Wiskott-Aldrich syndrome protein (WASP), is accompanied with thrombocytopenia and a small platelet size [28]. Platelets from mice deficient in WASP are decreased in ability to clot retraction, likely because of abnormal actin filament formation [81]. A similar phenotype is observed in platelets from Wiskott-Aldrich syndrome patients.

In human (thrombin-stimulated) platelet-rich plasma, weakened clot retraction is measured upon pharmacological inhibition of $\alpha_{\mathrm{IIb}} \beta_{3}, \mathrm{G} 13$ protein, Cbl or gap junction proteins (Table 4). Taken together, the findings with mouse and human platelets may indicate that especially impairments in sustained integrin activation, in platelet-platelet contacts or in actin filament formation lead to diminished clot retraction. Whether deficient clot retraction is a marker for impaired hemostasis (bleeding), is an attractive hypothesis. However, this has not systematically been studied.

\section{Conclusion}

Studies with both genetically modified mice and pharmacological inhibitors indicate that, in collagen-adhered platelets, in part common signaling pathways lead to PS exposure (procoagulant activity), generation of thrombin and fibrin, and retraction of the fibrin clot. However, signaling events causing prolonged $\mathrm{Ca}^{2+}$ elevation particularly stimulate PS exposure and thrombin generation, whereas integrin-dependent signaling events rather enforce fibrin clot retraction. Contact-dependent signaling pathways, triggered by homotypic platelet-platelet interactions, seem to act via the integrin route.

\section{Acknowledgements}

This work was supported by grants from the Center for Translational Molecular Medicine (INCOAG), the Netherlands Heart Foundation (2011T6) and ZonMW (MKMD 114021004). 


\section{Conflict of interest statement}

The authors report no relevant conflicts of interest.

\section{References}

[1] Versteeg HH, Heemskerk JW, Levi M, Reitsma PH. New fundamentals in hemostasis. Physiol Rev 2013;93:327-58.

[2] Monroe DM, Hoffman M. What does it take to make the perfect clot? Arterioscler Thromb Vasc Biol 2006;26:41-8.

[3] Van Kruchten R, Cosemans JM, Heemskerk JW. Measurement of whole blood thrombus formation using parallel-plate flow chambers: a practical guide. Platelets 2012;23:229-42.

[4] Jackson SP. The growing complexity of platelet aggregation. Blood 2007; 109:5087-95.

[5] Cosemans JM, Angelillo-Scherrer A, Mattheij NJ, Heemskerk JW. The effects of arterial flow on platelet activation, thrombus growth, and stabilization. Cardiovasc Res 2013;99:342-52.

[6] Munnix IC, Kuijpers MJ, Auger J, Thomassen CM, Panizzi P, van Zandvoort MA, et al. Segregation of platelet aggregatory and procoagulant microdomains in thrombus formation. Arterioscler Thromb Vasc Biol 2007;27:2484-90.

[7] Mattheij NJ, Gilio K, van Kruchten R, Jobe SM, Wieschhaus AJ, Chishti AH, et al. Dual mechanism of integrin $\alpha_{\mathrm{II}} \beta_{3}$ closure in procoagulant platelets. J Biol Chem 2013;288:13325-36.

[8] Heemskerk JW, Mattheij NJ, Cosemans JM. Platelet-based coagulation: different populations, different functions. J Thromb Haemost 2013;11:2-16.

[9] Munnix IC, Cosemans JM, Auger JM, Heemskerk JW. Platelet response heterogeneity in thrombus formation. Thromb Haemost 2009;102:114956.

[10] Heemskerk JW, Kuijpers MJ, Munnix IC, Siljander PR. Platelet collagen receptors and coagulation. A characteristic platelet response as possible target for antithrombotic treatment. Trends Cardiovasc Med 2005;15:8692.

[11] Cosemans JM, Kuijpers MJ, Lecut C, Loubele ST, Heeneman S, Jandrot-Perrus $\mathrm{M}$, et al. Contribution of platelet glycoprotein VI to the thrombogenic effect of collagens in fibrous atherosclerotic lesions. Atherosclerosis 2005; 181:19-27.

[12] Nergiz-Ünal R, Cosemans JM, Feijge MA, van der Meijden PE, Storey $\mathrm{RF}$, van Giezen JJ, et al. Stabilizing role of platelet $\mathrm{P} 2 \mathrm{Y}_{12}$ receptors in shear-dependent thrombus formation on ruptured plaques. Plos One 2010;5:e10130.

[13] Van der Meijden PE, Feijge MA, Giesen PL, Huijberts M, van Raak LP, Heemskerk JW. Platelet P2Y $\mathrm{Y}_{12}$ receptors enhance signalling towards procoagulant activity and thrombin generation. A study with healthy subjects and patients at thrombotic risk. Thromb Haemost 2005;93:112836.

[14] Cosemans JM, van Kruchten R, Olieslagers S, Schurgers LJ, Verheyen FK, Munnix IC, et al. Potentiating role of Gas6 and Tyro3, Axl and Mer (TAM) receptors in human and murine platelet activation and thrombus stabilization. J Thromb Haemost 2010;8:1797-808.

[15] Varga-Szabo D, Braun A, Nieswandt B. STIM and Orai in platelet function. Cell Calcium 2011;50:270-8

[16] Varga-Szabo D, Braun A, Kleinschnitz C, Bender M, Pleines I, Pham M, et al The calcium sensor STIM1 is an essential mediator of arterial thrombosis and ischemic brain infarction. J Exp Med 2008;205:1583-91.

[17] Gilio K, van Kruchten R, Braun A, Berna-Erro A, Feijge MA, Stegner D, et al. Roles of platelet STIM1 and Orai1 in glycoprotein VI- and thrombindependent procoagulant activity and thrombus formation. J Biol Chem 2010;285:23629-38.

[18] Van Kruchten R, Braun A, Feijge MA, Kuijpers MJ, Rivera-Galdos R, Kraft $P$, et al. Antithrombotic potential of blockers of store-operated calcium channels in platelets. Arterioscler Thromb Vasc Biol 2012;32:1717-23.

[19] Harper MT, Londono JE, Quick K, Londono JC, Flockerzi V, Philipp SE, et al. Transient receptor potential channels function as a coincidence signal detector mediating phosphatidylserine exposure. Sci Signal 2013;6:ra50.

[20] Choo HJ, Saafir TB, Mkumba L, Wagner MB, Jobe SM. Mitochondrial calcium and reactive oxygen species regulate agonist-initiated platelet phosphatidylserine exposure. Arterioscler Thromb Vasc Biol 2012;32:2946-55.

[21] Remenyi G, Szasz R, Friese P, Dale GL. Role of mitochondrial permeability transition pore in coated-platelet formation. Arterioscler Thromb Vasc Biol 2005;25:467-71.

[22] Jobe SM, Wilson KM, Leo L, Raimondi A, Molkentin JD, Lentz SR, et al. Critical role for the mitochondrial permeability transition pore and cyclophilin D in platelet activation and thrombosis. Blood 2008;111:125765.

[23] Ahmad F, Boulaftali Y, Greene TK, Ouellette TD, Poncz M, Feske S, et al. Relative contributions of stromal interaction molecule 1 and CalDAGGEFI to calcium-dependent platelet activation and thrombosis. J Thromb Haemost 2011;9:2077-86.
[24] Heemskerk JW, Harper MT, Cosemans JM, Poole AW. Unravelling the different functions of protein kinase $\mathrm{C}$ isoforms in platelets. FEBS Lett 2011;585:1711-6.

[25] Strehl A, Munnix IC, Kuijpers MJ, van der Meijden PE, Cosemans JM, Feijge MA, et al. Dual role of platelet protein kinase $C$ in thrombus formation: stimulation of pro-aggregatory and suppression of procoagulant activity in platelets. J Biol Chem 2007;282:7046-55.

[26] Hall KJ, Harper MT, Gilio K, Cosemans JM, Heemskerk JW, Poole AW. Genetic analysis of the role of protein kinase $\mathrm{C} \theta$ in platelet function and thrombus formation. Plos One 2008;3:e3277.

[27] Gilio K, Munnix IC, Mangin P, Cosemans JM, Feijge MA, van der Meijden PE, et al. Non-redundant roles of phosphoinositide 3-kinase isoforms $\alpha$ and $\beta$ in glycoprotein $\mathrm{VI-induced} \mathrm{platelet} \mathrm{signaling} \mathrm{and} \mathrm{thrombus} \mathrm{formation.} \mathrm{J}$ Biol Chem 2009;284:33750-62.

[28] Nurden AT, Freson K, Seligsohn U. Inherited platelet disorders. Haemophilia 2012;18 Suppl 4:154-60.

[29] Blair P, Flaumenhaft R. Platelet a-granules: basic biology and clinical correlates. Blood Rev 2009;23:177-89.

[30] Deppermann C, Cherpokova D, Nurden P, Schulz JN, Thielmann I, Kraft P, et al. Gray platelet syndrome and defective thrombo-inflammation in Nbeal2deficient mice. J Clin Invest 2013;123:3331-42.

[31] Gupta S, Braun A, Morowski M, Premsler T, Bender M, Nagy Z, et al. CLP36 is a negative regulator of glycoprotein VI signaling in platelets. Circ Res 2012;111:1410-20.

[32] Bauer K, Kratzer M, Otte M, de Quintana KL, Hagmann J, Arnold GJ, et al. Human CLP36, a PDZ-domain and LIM-domain protein, binds to $\alpha$-actinin- 1 and associates with actin filaments and stress fibers in activated platelets and endothelial cells. Blood 2000;96:4236-45.

[33] Munnix IC, Strehl A, Kuijpers MJ, Auger JM, van der Meijden PE, van Zandvoort MA, et al. The glycoprotein VI-phospholipase $C \gamma 2$ signaling pathway controls thrombus formation induced by collagen and tissue factor in vitro and in vivo. Arterioscler Thromb Vasc Biol 2005;25:2673-8.

[34] Van der Meijden PE, Munnix IC, Auger JM, Govers-Riemslag JW, Cosemans JM, Kuijpers MJ, et al. Dual role of collagen in factor XII-dependent thrombus formation. Blood 2009; 114:881-90.

[35] Kuijpers MJ, Munnix IC, Cosemans JM, van Vlijmen B, Reutelingsperger $\mathrm{CP}$, oude Egbrink MO, et al. Key role of platelet procoagulant activity in tissue factor-and collagen-dependent thrombus formation in arterioles and venules in vivo differential sensitivity to thrombin inhibition. Microcirculation 2008;15:269-82.

[36] Konings J, Govers-Riemslag JW, Philippou H, Mutch NJ, Borissoff JI, Allan $\mathrm{P}$, et al. Factor XIIa regulates the structure of the fibrin clot independently of thrombin generation through direct interaction with fibrin. Blood 2011;118:3942-51.

[37] Cosemans JM, Schols SE, Stefanini L, de Witt S, Feijge MA, Hamulyak $\mathrm{K}$, et al. Key role of glycoprotein Ib/V/IX and von Willebrand factor in platelet activation-dependent fibrin formation at low shear flow. Blood 2011;117:651-60.

[38] Fox JE. Identification of actin-binding protein as the protein linking the membrane skeleton to glycoproteins on platelet plasma membranes. J Biol Chem 1985;260:11970-7.

[39] Okita JR, Pidard D, Newman PJ, Montgomery RR, Kunicki TJ. On the association of glycoprotein $\mathrm{Ib}$ and actin-binding protein in human platelets. J Cell Biol 1985;100:317-21.

[40] Berny MA, Munnix IC, Auger JM, Schols SE, Cosemans JM, Panizzi P, et al. Spatial distribution of factor Xa, thrombin, and fibrin(ogen) on thrombi at venous shear. Plos One 2010;5:e10415.

[41] Fuchs TA, Brill A, Duerschmied D, Schatzberg D, Monestier M, Myers DD, et al. Extracellular DNA traps promote thrombosis. Proc Natl Acad Sci USA 2010;107:15880-5.

[42] Von Bruhl ML, Stark K, Steinhart A, Chandraratne S, Konrad I, Lorenz M, et al. Monocytes, neutrophils, and platelets cooperate to initiate and propagate venous thrombosis in mice in vivo. J Exp Med 2012;209:819-35.

[43] Brinkmann V, Reichard U, Goosmann C, Fauler B, Uhlemann Y, Weiss DS, et al. Neutrophil extracellular traps kill bacteria. Science 2004;303:1532-5.

[44] Clark SR, Ma AC, Tavener SA, McDonald B, Goodarzi Z, Kelly MM, et al Platelet TLR4 activates neutrophil extracellular traps to ensnare bacteria in septic blood. Nat Med 2007;13:463-9.

[45] Calderwood DA. Integrin activation. J Cell Sci 2004:117:657-66.

[46] Shattil SJ, Newman PJ. Integrins: dynamic scaffolds for adhesion and signaling in platelets. Blood 2004;104:1606-15.

[47] Gachet C. P2 receptors, platelet function and pharmacological implications. Thromb Haemost 2008;99:466-72.

[48] Cosemans JM, Munnix IC, Wetzker R, Heller R, Jackson SP, Heemskerk JW. Continuous signaling via PI $3 \mathrm{~K}$ isoforms $\mathrm{b}$ and $\mathrm{g}$ is required for platelet ADP receptor function in dynamic thrombus stabilization. Blood 2006; $108: 3045-52$.

[49] Goto S, Tamura N, Ishida H, Ruggeri ZM. Dependence of platelet thrombus stability on sustained glycoprotein IIb/IIIa activation through adenosine 5'-diphosphate receptor stimulation and cyclic calcium signaling. J Am Coll Cardiol 2006;47:155-62. 
[50] Angelillo-Scherrer A, Burnier L, Flores N, Savi P, DeMol M, Schaeffer P, et al. Role of Gas6 receptors in platelet signaling during thrombus stabilization and implications for antithrombotic therapy. J Clin Invest 2005;115:237-46.

[51] Bergmeier W, Stefanini L. Novel molecules in calcium signaling in platelets. J Thromb Haemost 2009; 7 Suppl 1:187-90.

[52] Honda A, Nogami M, Yokozeki T, Yamazaki M, Nakamura H, Watanabe $\mathrm{H}$, et al. Phosphatidylinositol 4-phosphate 5-kinase a is a downstream effector of the small G protein ARF6 in membrane ruffle formation. Cell 1999;99:521-32.

[53] Martel V, Racaud-Sultan C, Dupe S, Marie C, Paulhe F, Galmiche A, et al. Conformation, localization, and integrin binding of talin depend on its interaction with phosphoinositides. J Biol Chem 2001;276:21217-27.

[54] Elvers M, Stegner D, Hagedorn I, Kleinschnitz C, Braun A, Kuijpers ME, et al. Impaired $\alpha_{\mathrm{II}} \beta_{3}$ integrin activation and shear-dependent thrombus formation in mice lacking phospholipase D1. Sci Signal 2010;3:ra1.

[55] Romaniuk MA, Croci DO, Lapponi MJ, Tribulatti MV, Negrotto S, Poirier $\mathrm{F}$, et al. Binding of galectin-1 to $\alpha_{\mathrm{II}} \beta_{3}$ integrin triggers outside-in signals, stimulates platelet activation, and controls primary hemostasis. FASEB J 2012;26:2788-98

[56] Brass LF, Stalker TJ, Zhu L, Lu B, Woulfe DS, Prevost N. Boundary events: contact-dependent and contact-facilitated signaling between platelets. Sem Thromb Hemost 2004;30:399-410.

[57] Goodenough DA, Paul DL. Beyond the gap: functions of unpaired connexon channels. Nat Rev Mol Cell Biol 2003;4:285-94.

[58] Goodenough DA, Paul DL. Gap junctions. Cold Spring Harbor Perspec Biol 2009; $1: 25-76$

[59] Vaiyapuri S, Jones CI, Sasikumar P, Moraes LA, Munger SJ, Wright JR, et al. Gap junctions and connexin hemichannels underpin hemostasis and thrombosis. Circulation 2012;125:2479-91.

[60] Vaiyapuri S, Moraes LA, Sage T, Ali MS, Lewis KR, Mahaut-Smith MP, et al. Connexin40 regulates platelet function. Nat Commun 2013;4:2564.

[61] Naik MU, Stalker TJ, Brass LF, Naik UP. JAM-A protects from thrombosis by suppressing integrin $\alpha_{\mathrm{II}} \beta_{3}$-dependent outside-in signaling in platelets. Blood 2012;119:3352-60.

[62] Ozaki H, Ishii K, Arai H, Horiuchi H, Kawamoto T, Suzuki H, et al. Junctional adhesion molecule (JAM) is phosphorylated by protein kinase $\mathrm{C}$ upon platelet activation. Biochem Biophys Res Commun 2000;276:873-8.

[63] Kornecki E, Walkowiak B, Naik UP, Ehrlich YH. Activation of human platelets by a stimulatory monoclonal antibody. J Biol Chem 1990;265:10042-8.

[64] Naik UP, Ehrlich YH, Kornecki E. Mechanisms of platelet activation by a stimulatory antibody: cross-linking of a novel platelet recepto for monoclonal antibody F11 with the Fc $\gamma$ RII receptor. Biochem J 1995;310:155-62.

[65] Obergfell A, Eto K, Mocsai A, Buensuceso C, Moores SL, Brugge JS, et al. Coordinate interactions of Csk, Src, and Syk kinases with $\alpha_{11 \mathrm{~b}} \beta_{3}$ initiate integrin signaling to the cytoskeleton. J Cell Biol 2002;157:265-75.

[66] Jackson DE, Ward CM, Wang R, Newman PJ. The protein-tyrosine phosphatase SHP-2 binds platelet/endothelial cell adhesion molecule-1 (PECAM-1) and forms a distinct signaling complex during platelet aggregation. J Biol Chem 1997;272:6986-93.

[67] Stalker TJ, Wu J, Morgans A, Traxler EA, Wang L, Chatterjee MS, et al. Endothelial cell specific adhesion molecule (ESAM) localizes to plateletplatelet contacts and regulates thrombus formation in vivo. J Thromb Haemost 2009;7:1886-96.

[68] Tomlinson MG. Platelet tetraspanins: small but interesting. J Thromb Haemost. 2009; 7:2070-3.

[69] Stipp CS, Kolesnikova TV, Hemler ME. Functional domains in tetraspanin proteins. Trends Biochem Sci 2003;28:106-12.

[70] Goschnick MW, Lau LM, Wee JL, Liu YS, Hogarth PM, Robb LM, et al. Impaired outside-in integrin $\alpha_{1 \mathrm{~b}} \beta_{3}$ signaling and thrombus stability in TSSC6-deficient mice. Blood 2006;108:1911-8.

[71] Lau LM, Wee JL, Wright MD, Moseley GW, Hogarth PM, Ashman LK, et al. The tetraspanin superfamily member CD151 regulates outside-in integrin $\alpha_{\mathrm{IIb}} \beta_{3}$ signaling and platelet function. Blood 2004;104:2368-75.

[72] Dhanjal TS, Ross EA, Auger JM, McCarty OJ, Hughes CE, Senis YA, et al. Minimal regulation of platelet activity by PECAM-1. Platelets 2007;18:5667.

[73] Patil S, Newman DK, Newman PJ. Platelet endothelial cell adhesion molecule- 1 serves as an inhibitory receptor that modulates platelet responses to collagen. Blood 2001;97:1727-32.

[74] Rathore V, Stapleton MA, Hillery CA, Montgomery RR, Nichols TC, Merricks EP, et al. PECAM-1 negatively regulates GPIb/V/IX signaling in murine platelets. Blood 2003;102:3658-64.

[75] Martin V, Guillermet-Guibert J, Chicanne G, Cabou C, Jandrot-Perrus M, Plantavid M, et al. Deletion of the $\mathrm{p} 110 \beta$ isoform of phosphoinositide 3-kinase in platelets reveals its central role in Akt activation and thrombus formation in vitro and in vivo. Blood 2010;115:2008-13.

[76] Schoenwaelder SM, Ono A, Nesbitt WS, Lim J, Jarman K, Jackson SP. Phosphoinositide 3-kinase $p 110 \beta$ regulates integrin $\alpha_{11 \mathrm{~b}} \beta_{3}$ avidity and the cellular transmission of contractile forces. J Biol Chem 2010;285:2886-96.
[77] Ono A, Westein E, Hsiao S, Nesbitt WS, Hamilton JR, Schoenwaelder SM, et al. Identification of a fibrin-independent platelet contractile mechanism regulating primary hemostasis and thrombus growth. Blood 2008;112:909.

[78] Auger JM, Watson SP. Dynamic tyrosine kinase-regulated signaling and actin polymerisation mediate aggregate stability under shear. Arterioscler Thromb Vasc Biol 2008;28:1499-504.

[79] Pleines I, Hagedorn I, Gupta S, May F, Chakarova L, van Hengel J, et al. Megakaryocyte-specific RhoA deficiency causes macrothrombocytopenia and defective platelet activation in hemostasis and thrombosis. Blood 2012;119:1054-63.

[80] Buitrago L, Tsygankov A, Sanjay A, Kunapuli SP. Cbl proteins in platelet activation. Platelets 2013;24:419-27.

[81] Shcherbina A, Cooley J, Lutskiy MI, Benarafa C, Gilbert GE, RemoldO'Donnell E. WASP plays a novel role in regulating platelet responses dependent on $\alpha_{\mathrm{Ib}} \beta_{3}$ integrin outside-in signalling. Br J Haematol 2010;148:416-27.

[82] Kuijpers MJ, Schulte V, Oury C, Lindhout T, Broers J, Hoylaerts MF, et al. Facilitating roles of murine platelet glycoprotein Ib and $\alpha_{\mathrm{IIb}} \beta_{3}$ in phosphatidylserine exposure during vWF-collagen-induced thrombus formation. J Physiol 2004;558:403-15.

[83] Kuijpers MJ, Schulte V, Bergmeier W, Lindhout T, Brakebusch C, Offermanns $\mathrm{S}$, et al. Complementary roles of glycoprotein VI and $\alpha_{2} \beta_{1}$ integrin in collagen-induced thrombus formation in flowing whole blood ex vivo. FASEB J 2003; 17:685-7.

[84] Nieswandt B, Brakebusch C, Bergmeier W, Schulte V, Bouvard D, MokhtariNejad R, et al. Glycoprotein VI but not $\alpha_{2} \beta_{1}$ integrin is essential for platelet interaction with collagen. EMBO J 2001;20:2120-30.

[85] Auger JM, Kuijpers MJ, Senis YA, Watson SP, Heemskerk JW. Adhesion of human and mouse platelets to collagen under shear: a unifying model. FASEB J 2005; 19:825-7.

[86] Consonni A, Cipolla L, Guidetti G, Canobbio I, Ciraolo E, Hirsch E, et al. Role and regulation of phosphatidylinositol 3-kinase $\beta$ in platelet integrin $\alpha_{2} \beta_{1}$ signaling. Blood 2012;119:847-56.

[87] Gilio K, Harper MT, Cosemans JM, Konopatskaya O, Munnix IC, Prinzen L, et al. Functional divergence of platelet protein kinase $C(P K C)$ isoforms in thrombus formation on collagen. J Biol Chem 2010;285:23410-9.

[88] Konopatskaya O, Gilio K, Harper MT, Zhao Y, Cosemans JM, Karim ZA, et al. $\mathrm{PKC} \alpha$ regulates platelet granule secretion and thrombus formation in mice. J Clin Invest 2009;119:399-407.

[89] Konopatskaya O, Matthews SA, Harper MT, Gilio K, Cosemans JM, Williams $\mathrm{CM}$, et al. Protein kinase $\mathrm{C}$ mediates platelet secretion and thrombus formation through protein kinase D2. Blood 2011;118:416-24.

[90] Elvers M, Pozgaj R, Pleines I, May F, Kuijpers MJ, Heemskerk JM, et al. Platelet hyperreactivity and a prothrombotic phenotype in mice with a gain-of-function mutation in phospholipase $C \gamma 2$. J Thromb Haemost 2010;8:1353-63.

[91] Lecut C, Schoolmeester A, Kuijpers MJ, Broers JL, van Zandvoort MA Vanhoorelbeke K, et al. Principal role of glycoprotein VI in $\alpha_{2} \beta_{1}$ and $\alpha_{\mathrm{IIb}} \beta_{3}$ activation during collagen-induced thrombus formation. Arterioscler Thromb Vasc Biol 2004;24:1727-33.

[92] Munnix IC, Gilio K, Siljander PR, Raynal N, Feijge MA, Hackeng TM, et al. Collagen-mimetic peptides mediate flow-dependent thrombus formation by high- or low-affinity binding of integrin $\alpha_{2} \beta_{1}$ and glycoprotein VI. J Thromb Haemost 2008;6:2132-42.

[93] Siljander PR, Munnix IC, Smethurst PA, Deckmyn H, Lindhout T, Ouwehand $\mathrm{WH}$, et al. Platelet receptor interplay regulates collagen-induced thrombus formation in flowing human blood. Blood 2004;103:1333-41.

[94] Van de Walle GR, Schoolmeester A, Iserbyt BF, Cosemans JM, Heemskerk JW, Hoylaerts MF, et al. Activation of $\alpha_{\mathrm{Ib}} \beta_{3}$ is a sufficient but also an imperative prerequisite for activation of $\alpha_{2} \beta_{1}$ on platelets. Blood 2007; 109:595-602.

[95] Hodivala-Dilke KM, McHugh KP, Tsakiris DA, Rayburn H, Crowley D, Ullman-Cullere $M$, et al. $\beta_{3}$-integrin-deficient mice are a model for Glanzmann thrombasthenia showing placental defects and reduced survival. J Clin Invest 1999;103:229-38.

[96] Yang H, Kim A, David T, Palmer D, Jin T, Tien J, et al. TMEM16F forms a $\mathrm{Ca}^{2+}$ activated cation channel required for lipid scrambling in platelets during blood coagulation. Cell. 2012;151:111-22.

[97] Randriamboavonjy V, Isaak J, Fromel T, Viollet B, Fisslthaler B, Preissner KT et al. AMPK $\alpha 2$ subunit is involved in platelet signaling, clot retraction, and thrombus stability. Blood 2010;116:2134-40.

[98] Chen X, Zhang Y, Wang Y, Li D, Zhang L, Wang K, et al. PDK1 regulates platelet activation and arterial thrombosis. Blood 2013;121:3718-26.

[99] Gushiken FC, Hyojeong H, Pradhan S, Langlois KW, Alrehani N, Cruz MA, et al. The catalytic subunit of protein phosphatase $1 \gamma$ regulates thrombininduced murine platelet $\alpha_{11} \beta_{3}$ function. Plos One 2009;4:e8304

[100] Kuchay SM, Kim N, Grunz EA, Fay WP, Chishti AH. Double knockouts reveal that protein tyrosine phosphatase $1 \mathrm{~B}$ is a physiological target of calpain-1 in platelets. Mol Cell Biol 2007;27:6038-52.

[101] Arias-Salgado EG, Haj F, Dubois C, Moran B, Kasirer-Friede A, Furie BC, et al. 
PTP-1B is an essential positive regulator of platelet integrin signaling. J Cell Biol 2005;170:837-45.

[102] Stefanini L, Boulaftali Y, Ouellette TD, Holinstat M, Desire L, Leblond B, et al. Rap1-Rac1 circuits potentiate platelet activation. Arterioscler Thromb Vasc Biol 2012;32:434-41.

[103] Zhang G, Xiang B, Ye S, Chrzanowska-Wodnicka M, Morris AJ, Gartner TK, et al. Distinct roles for Rap1b protein in platelet secretion and integrin $\alpha_{\mathrm{II}} \beta_{3}$ outside-in signaling. J Biol Chem 2011;286:39466-77.

[104] Haling JR, Monkley SJ, Critchley DR, Petrich BG. Talin-dependent integrin activation is required for fibrin clot retraction by platelets. Blood 2011; $117: 1719-22$.

[105] Buitrago L, Langdon WY, Sanjay A, Kunapuli SP. Tyrosine phosphorylated c-Cbl regulates platelet functional responses mediated by outside-in signaling. Blood 2011;118:5631-40.

[106] Takizawa H, Nishimura S, Takayama N, Oda A, Nishikii H, Morita Y, et al. Lnk regulates integrin $\alpha_{\mathrm{IIb}} \beta_{3}$ outside-in signaling in mouse platelets, leading to stabilization of thrombus development in vivo. J Clin Invest 2010;120:179-90.

[107] Weyrich AS, Denis MM, Schwertz H, Tolley ND, Foulks J, Spencer E, et al. mTOR-dependent synthesis of Bcl-3 controls the retraction of fibrin clots by activated human platelets. Blood 2007;109:1975-83.

[108] Spinelli SL, Casey AE, Pollock SJ, Gertz JM, McMillan DH, Narasipura SD, et al. Platelets and megakaryocytes contain functional nuclear factor-kappaB. Arterioscler Thromb Vasc Biol 2010;30:591-8.

[109] Zhao Y, Zhang Y, Wang S, Hua Z, Zhang J. The clock gene Per2 is required for normal platelet formation and function. Thromb Res 2011;127:122-30.

[110] Feijge MA, Ansink K, Vanschoonbeek K, Heemskerk JW. Control of platelet activation by cyclic AMP turnover and cyclic nucleotide phosphodiesterase type-3. Biochem Pharmacol 2004;67:1559-67.
[111] Suzuki-Inoue K, Hughes CE, Inoue O, Kaneko M, Cuyun-Lira O, Takafuta T, et al. Involvement of Src kinases and PLC $\gamma 2$ in clot retraction. Thromb Res 2007; $120: 251-8$

[112] Severin S, Gratacap MP, Lenain N, Alvarez L, Hollande E, Penninger JM, et al. Deficiency of Src homology 2 domain-containing inositol 5-phosphatase 1 affects platelet responses and thrombus growth. J Clin Invest 2007; 117:944-52.

[113] Lecut C, Feijge MA, Cosemans JM, Jandrot-Perrus M, Heemskerk JW. Fibrillar type I collagens enhance platelet-dependent thrombin generation via glycoprotein VI with direct support of $\alpha_{2} \beta_{1}$ but not $\alpha_{\mathrm{Ib}} \beta_{3}$ integrin. Thromb Haemost 2005;94:107-14.

[114] Vanschoonbeek K, Feijge MA, van Kampen RJ, Kenis H, Hemker HC, Giesen PL, et al. Initiating and potentiating role of platelets in tissue factor-induced thrombin generation in the presence of plasma: subjectdependent variation in thrombogram characteristics. J Thromb Haemost 2004;2:476-84.

[115] Gong H, Shen B, Flevaris P, Chow C, Lam SC, Voyno-Yasenetskaya TA, et al. $G$ protein subunit Ga13 binds to integrin $\alpha_{m} \beta_{3}$ and mediates integrin “outside-in" signaling. Science 2010;327:340-3.

[116] Kannan M, Ahmed RP, Jain P, Kumar R, Choudhry VP, Saxena R. Type I Glanzmann thrombasthenia: most common subtypes in North Indians. Am J Hematol 2003;74:139-41.

[117] Van der Meijden PE, Schoenwaelder SM, Feijge MA, Cosemans JM, Munnix IC, Wetzker R, et al. Dual P2Y ${ }_{12}$ receptor signaling in thrombin-stimulated platelets: involvement of phosphoinositide 3-kinase $\beta$ but not $\gamma$ isoform in $\mathrm{Ca}^{2+}$ mobilization and procoagulant activity. FEBS J 2008;275:371-85.

[118] Van der Meijden PE, Feijge MA, Swieringa F, Gilio K, Nergiz-Unal R, Hamulyak K, et al. Key role of integrin $\alpha_{\mathrm{lb}} \beta_{3}$ signaling to Syk kinase in tissue factor-induced thrombin generation. Cel Mol Life Sci 2012;69:348192. 